\title{
Persepsi Siswa Terhadap Kegiatan Ekstrakurikuler Pramuka pada Sekolah Menengah Kejuruan (SMK) di Kecamatan Padang Timur
}

\author{
Anggia Tamara ${ }^{1}$, Ahmad Sabandi ${ }^{2}$,Hanif Al Kadri ${ }^{3}$,Yulianto Santoso ${ }^{4}$ \\ 1,2,3,4Administrasi Pendidikan, Universitas Negeri Padang
}

Anggia Tamara1 ${ }^{1}$ e-mail: anggiatamara11@gmail.com

Ahmad Sabandi² e-mail:sabandi@fip.unp.ac.id

Hanif Al Kadri³ e-mail:hanifalkadri@fip.unp.ac.id

Yulianto Santoso 4 e-mail:yuliantosantoso2015@gmail.com

\begin{abstract}
This research aims to get information about students' perception of scout extracurricular activities in vocational schools in east Padang subdistrict as seen from indicators of interest, attitude, motivation, attention, appreciation and expectations. The type of research used is descriptive research using quantitative methods. In this research, the population of students at SMK in East Padang subdistrict which amounted to 325 students, the large sample taken was 76 respondents. The withdrawal of samples in this research using Proportional Stratified Random Sampling. Data collection using questionnaires with likert scale has been tested for validity and reliability. The average formulation is used in processing data in this research. The data showed the response of students regarding scout extracurricular activities at vocational schools in east Padang regarding scout extracurricular activities at vocational schools in east padang subdistrict from: (1) the interest aspect is getting an average score of 2.53 with a respondent achievement rate (TCR) of $58.8 \%$ in the low category; (2) aspect of attitude are getting an average score of 2.65 and the respondent's achievement rate (TCR) of $61.8 \%$ in the low category; (3) the motivational aspect is to get an average score of 2.61 and the respondent's achievement rate (TCR) of $57.2 \%$ in the low category; (4) the attention aspect is to get an average score 2.59 and the respondent's achievement rate (TCR) of $60.6 \%$ in the low category; (5) the aspect of appreciation is to get an average score of 2.47 with a respondent's achievement rate (TCR) of $57.7 \%$ in the low category; (6) the aspect of expectation is to get an average score of $2.41 \%$ and the respondent's achievement rate (TCR) of $57.0 \%$ in the low category. Overall, student's perception of scout extracurricular activities in vocational schools in east Padang subdistrict scored an average of 2.54 with a respondent's achievement rate (TCR) of $58.85 \%$ in the low category.
\end{abstract}

\begin{abstract}
Abstrak
Penelitian ini bertujuan untuk mendapatkan informasi mengenai persepsi siswa terhadap kegiatan ekstrakurikuler pramuka pada SMK di kecamatan padang timur dilihat dari indikator minat, sikap, motivasi, perhatian, apresiasi, dan harapan. Jenis penelitian yang digunakan adalah penelitian deskriptif dengan menggunakan metode kuantitatif. Dalam penelitian ini populasinya yaitu siswa pada SMK di kecamatan Padang Timur yang berjumlah 325 siswa maka besar sampel yang diambil adalah 76 responden. Penarikan sampel pada penelitian ini menggunakan teknik Proportional Stratified Random Sampling.Pengumpulan data menggunakan angket dengan skala likert telah diuji validitas dan reliabilitasnya. Rumusan ratarata digunakan dalam mengolah data pada penelitian ini. Data menunjukkan tanggapan siswa mengenai kegiatan ekstrakurikuler pramuka pada SMK di kecamatan padang timur dari: (1) Aspek minat yaitu mendapatkan skor rata-rata 2.53 dengan tingkat capaian responden (TCR) $58,8 \%$ dalam kategori rendah; (2) aspek sikap yaitu mendapatkan skor rata-rata 2.65 dan tingkat capaian responden (TCR) 61,8\% dalam kategori rendah; (3) aspek motivasi yaitu mendapatkan skor rata-rata 2.61 dan tingkat capaian responden (TCR) 57,2\% dalam kategori rendah; (4) aspek perhatian yaitu mendapatkan skor rata-rata 2.59 dan tingkat capaian responden (TCR) 60,6\% dalam kategori rendah; (5) aspek apresiasi yaitu mendapatkan skor rata-rata 2.47 dengan tingkat capaian responden (TCR) 57,7\% dalam kategori rendah; (6) aspek harapan yaitu mendapatkan skor rata-rata 2,41 dan tingkat capaian responden (TCR) 57,0\% dalam kategori rendah. Secara keseluruhan Persepsi siswa terhadap kegiatan ekstrakurikuler pramuka pada SMK di Kecamatan padang timur mendapatkan skor rata-rata 2,54 dengan tingkat capaian responden (TCR) 58,85\% dalam kategori rendah.
\end{abstract}


Kata kunci :Persepsi, Ekstrakurikuler Pramuka

How to Cite: AnggiaTamara1, Ahmad Sabandi2, Hanif Al Kadri3, Yulianto Santoso 4, 2021.Persepsi Siswa Terhadap Kegiatan Ekstrakurikuler Pramuka Pada Sekolah Menengah Kejuruan (SMK) di kecamatan Padang Timur. Journal Educational Administrasi and Leadership, Vol (N): pp.XXXX,DOI:10.24036/XXXXXXXXXX-X-XX

This is an open access article distributed under the Creative Commons 4.0 Attribution License, which permits unrestricted use, distribution, and reproduction in any medium, provided the original work is properly cited. (C2020 by author.

\section{Pendahuluan}

Berdasarkan Nomor 63 Tahun 2014 pasal 1 Permendikbud disebutkan bahwa pendidikan dalam pramuka yaitu bagaimana cara membentuk kecakapan, akhlak mulia, dan pribadi seseorang melalui pengamalan nilainilai dan penghayatan kepramukaan.

Persepsi terhadap Kegiatan Kepramukaan di kalangan remaja pada jenjang Sekolah tergolong turun terutama pada SMK dibandingkan dengan Persepsi mereka terkait kegiatan kepramukaan karena Siswa merasakan keikutsertaan dalam kegiatan pramuka tidak lagi sesuai dengan porsi Pendidikan mereka (PortnovNeeman dan Barak: 2013)

Pendidikan Pramuka di indonesia adalah salah satu segi pendidikan nasional yang penting, juga bagian dari sejarah perjuangan bangsa indonesia. Seiring dengan perkembangan Pendidikan pramuka terlihat dari beberapa Sekolah meniadakan Sekolahnya dan mulai kurang diminati. Terlihat bahwa sekolah hanya menciptakan Pramuka sebagai salah satu kegiatan yang wajib diikuti semua Siswa, tapi dalam pelaksanaanya kurang mendapat perhatian dan pengawasan dari pihak sekolah karena pembina tidak terlihat ikut melakukan kegiatan disaat kegiatan tersebut sedang berlangsung. Kurangnya prasarana dan sarana yang ada untuk pelaksanaan kegiatan pramuka berakibat pada rendahnya keinginan siswa untuk mengikuti kegiatan ekstrakurikuler pramuka di SMK yang terdapat di Kecamatan Padang Timur .

Adapun tujuan dari ekstrakurikuler yaitu untuk menambah pengetahuan, wawasan dan kemampuan siswa. Selain itu, untuk membantu pengembanganSiswa sesuai dengan Potensi, Kebutuhan, pembinaan bakat dan minat serta kegemaran peserta didik.

Berdasarkan pemaparan diatas maka yang akan diteliti yaitu: 1) bagaimanakah persepsi siswa terhadap kegiatan ekstrakurikuler pramuka pada SMK di Kecamatan padang timur dilihat dari aspek minat?2) bagaimanakah persepsi siswa terhadap kegiatan ekstrakurikuler pramuka pada SMK di Kecamatan Padang Timur dilihat dari aspek sikap?3)bagaimanakah persepsi siswa terhadap kegiatan ekstrakurikuler pramuka pada SMK di Kecamatan Padang Timur dilihat dari aspek motivasi?4)bagaimanakah persepsi siswa terhadap kegiatan ekstrakurikuler pramuka pada SMK di kecamatan padang timur dilihat dari aspek perhatian?5) bagaimanakah persepsi siswa terhadap kegiatan ekstrakurikuler pramuka pada SMK di Kecamatan padang timur dilihat dari aspek apresiasi?6) bagaimanakah persepsi siswa terhadap kegiatan Ekstrakurikuler Pramuka pada SMK di Kecamatan Padang Timur dilihat dari aspek harapan?.

\section{Metode Penelitian}

Tempat yang dilakukan oleh peneliti adalah SMk.Jenis riset adalah kuantitatif. Siswa di kecamatan padang timur dari 6 sekolah yang berjumlah 325 siswa yang dijadikan populasinya dengan sampel 76 responden Serta memakai teknik proportional stratified random sampling. Riset ini memakai angket serta skala likert yang sudah di uji validitas dan reliabilitasnya, rumus rata-rata yang dilakukan untuk memperoleh data hasil penelitian.

\section{Hasil dan Bahasannya}

\subsection{Hasil}

Secara keseluruhan skor rata-rata tentang persepsi siswa terhadap kegiatan ekstrakurikuler pramuka pada SMK di Kecamatan Padang Timur dilihat dalam hal: a) aspek minat yaitu memperoleh skor rata-rata 2.53 dengan tingkat capaian responden (TCR) 58,8\% dalam kategori rendah, hal ini sangat perlu untuk ditingkatkan lagi oleh sekolah agar siswa memiliki minat yang tinggi dalam mengikuti kegiatan pramuka. b) aspek sikap yaitu memperoleh skor rata-rata 2.65 dengan tingkat capaian responden (TCR) 61,8\% dalam kategori rendah, hal ini perlu untuk ditingkatkan lagi oleh pembina pramuka agar siswa merubah sikap dari siswa dalam mengikuti pramuka. c) aspek motivasi yaitu memperoleh skor ratarata 2.61dengan tingkat capaian responden (TCR) 57,2\% dalam kategori rendah, Hal ini sangat perlu 
untuk diberikan peningkatan karena motivasi merupakan aspek penting yang memberi pengaruh besar bagi siswa dalam melakukan kegiatan pramuka. d) aspek perhatian yaitu memperoleh skor rata-rata 2.59 dengan tingkat capaian responden (TCR) 60,6\% dengan kategori rendah, hal ini menyatakan bahwa perhatian dalam mengikuti ekstrakurikuler kepramukaan pada SMK di kecamatan padang timur bisa dikatakan rendah. e) aspek apresiasi yaitu memperoleh skor rata-rata 2.47 dengan tingkat capaian responden (TCR) 57,7\% dalam kategori rendah, hal ini menunjukkan bahwa apresiasi dalam mengikuti ekstrakurikuler kepramukaan pada SMK di kecamatan padang timur bisa dikatakan rendah. f) aspek harapan yaitu memperoleh skor rata-rata 2.41dengan tingkat capaian responden (TCR) 57,0\% dalam kategori rendah, hal ini menunjukkan bahwa harapan dalam mengikuti ekstrakurikuler kepramukaan pada SMK di kecamatan padang timur bisa dikatakan rendah.

\subsection{Pembahasan}

Berdasarkan hasil dari penelitian persepsi siswa terhadap kegiatan ekstrakurikuler pramuka pada SMK di Kecamatan Padang Timur dilihat dari aspek minat mendapatkan skor rata-rata 2.53 dalam kategori rendah, aspek sikap yaitu mendapatkan skor rata-rata 2.65 dengan kategori rendah, aspek motivasi yaitu memperoleh skor rata-rata 2.61 dalam kategori rendah, aspek perhatian yaitu mendapatkan skor rata-rata 2.59 dalam kategori rendah, aspek apresiasi yaitu mendapatkan skor rata-rata 2.47 dalam kategori rendah, aspek harapan mendapatkan skor rata-rata 2.41 dengan kategori rendah.

Menurut (Thoha, 2015) persepsi seseorang dipengaruhi oleh faktor-faktor :

a. Aspek minat

Hasil penelitian menunjukkan bahwa skor tertinggi mengenai persepsi siswa dilihat dari aspek minat terdapat pada pernyataan saya tertarik menambah pengetahuan saya tentang kegiatan keterampilan pada ekstrakurikuler pramuka di sekolah yaitu memperoleh skor rata-rata 2.75 dengan tingkat capaian responden (TCR) $72,1 \%$ dalam kategori cukup. Sedangkan skor terendah pada pernyataan saya mendapat manfaat dengan saya mengikuti ekstrakurikuler pramuka yaitu memperoleh skor rata-rata 2,24 dengan tingkat capaian responden (TCR) 44,7\% dalam kategori sangat rendah. (Ikbal, 2011)

b. Aspek sikap

Hasil penelitian menunjukkan bahwa skor tertinggi mengenai persepsi siswa dilihat dari aspek sikap terdapat pada pernyataan belajar dalam kegiatan pramuka lebih menyenangkan dengan praktek di lapangan secara langsung yaitu memperoleh skor rata-rata 2.54 dengan tingkat capaian responden (TCR) $68,4 \%$ dalam kategori cukup. Sedangkan skor terendah pada pernyataan walaupun tidak menguasai kegiatan yang diajarkan pembina kegiatan, saya berusaha untuk melatihnya setiap ada waktu luang yaitu memperoleh skor rata-rata 2,59 dengan tingkat capaian responden (TCR) 47,6\% dalam kategori sangat rendah. (Naim, 2012)

c. Aspek motivasi

Hasil penelitian menunjukkan bahwa skor tertinggi mengenai persepsi siswa ditinjau dari aspek motivasi pada pernyataan belajar dalam kegiatan pramuka lebih menyenangkan dengan praktek dilapangan secara langsung yaitu memperoleh skor rata-rata 2.54 dengan singkat capaian responden (TCR) $68,4 \%$ dalam kategori cukup. Sedangkan skor terendah pada pernyataan walaupun tidak menguasai kegiatan yang diajarkan pembina kegiatan, saya berusaha untuk melatihnya setiap ada waktu luang yaitu memperoleh skor rata-rata 2,59 dengan tingkat capaian responden (TCR) 47,6\% dalam kategori sangat rendah.

d. Aspek perhatian

Hasil penelitian menunjukkan bahwa skor tertinggi mengenai persepsi siswa ditinjau dari aspek perhatian pada pernyataan ekstrakurikuler pramuka pada kegiatan mingguan yang diselenggarakan disekolah aktif saya ikuti yaitu memperoleh skor rata-rata 2.24 dengan tingkat capaian responden (TCR) $62,6 \%$ dalam kategori rendah. sedangkan skor terendah pada pernyataan muatan nilai sikap dan kecakapan pada ekstrakurikuler pramuka merupakan hal yang bisa diterapkan dalam kehidupan sosial sehari-hari yaitu memperoleh skor rata-rata 2,51 dengan tingkat capaian responden (TCR) 50,3\% sangat rendah. (Slameto, 2013)

e. Aspek apresiasi

Hasil penelitian menunjukkan bahwa skor tertinggi mengenai persepsi siswa ditinjau dari aspek apresiasi pada pernyataan bentuk kegiatan mingguan dan aktualisasi pada keterampilan pramuka yang monoton membuat saya merasa bosan yaitu memperoleh skor rata-rata 2.42 dengan tingkat capaian 
responden (TCR) 68,2\% dalam kategori cukup. Sedangkan skor terendah pada pernyataan dalam mengikuti kegiatan ekstrakurikuler pramuka, terdapat banyak pelajaran yang dapat digunakan dalam aktivitas sehari-hari yaitu memperoleh skor rata-rata 2,33 dengan tingkat capaian responden (TCR) 46,6\% dalam kategori sangat rendah. (Aminuddin, 2014)

f. Harapan

Hasil penelitian menunjukkan bahwa skor tertinggi mengenai persepsi siswa ditinjau dari aspek harapan pada pernyataan dengan mengikuti kegiatan ekstrakurikuler pramuka saya mendapat pengalaman pada keterampilan yang belum saya ketahui yaitu memperoleh skor rata-rata 2.64 dengan tingkat capaian responden (TCR) $72,4 \%$ dalam kategori cukup. Sedangkan skor terendah pada pernyataan bentuk keterampilan dalam berkemah (camping) pada kegiatan pramuka sebaiknya dikombinasikan dengan kegiatan lain seperti perlombaan atletik agar lebih menarik yaitu memperoleh skor rata-rata 2,25 dengan tingkat capaian responden (TCR) 41,9\% dalam kategori sangat rendah. (Burns, W, 2010)

\section{Kesimpulan}

Kesimpulan hasil dari penelitian mengenai persepsi siswa terhadap kegiatan ekstrakurikuler pramuka pada SMK di Kecamatan Padang Timur dilihat dari aspek minat mendapatkan skor rata-rata 2.53 dalam kategori rendah.aspek sikap mendapatkan skor rata-rata 2.65 dalam kategori rendah.aspek motivasi mendapatkan skor rata-rata 2.61 dengan kategori rendah. aspek perhatian mendapatkan skor rata-rata 2.59 dalam kategori rendah. aspek apresiasi mendapatkan skor rata-rata 2.47 dalam kategori rendah. aspek harapan mendapatkan skor rata-rata 2.41 dengan kategori rendah.

Jadi dari kesimpulan diatas, tentang persepsi siswa terhadap kegiatan ekstrakurikuler pramuka pada SMK di Kecamatan Padang Timur mendapatkan skor rata-rata 2,54 dengan tingkat capaian responden (TCR) $58,85 \%$ dalam kategori rendah. hal ini diharapkan agar sekolah terus meningkatkan lagi persepsi siswa SMK di Kecamatan Padang Timur agar kegiatan ekstrakurikuler menjadi lebih baik dan dilakukan dengan tanpa keterpaksaan dari siswa untuk melakukannya.

\section{Daftar Rujukan}

Aminuddin. (2014). Pengantar Apresiasi Karya Sastra. Bandung: Sinar Baru Algensindo.

Burns, W, G. (2010). Happiness, Healing, Enhancement. Canada: Jhon Wiley.

Ikbal, M. (2011). Pengaruh Motivasi terhadap minat Mahasiswa Akuntansi untuk Mengikuti Pendidikan Profesi Akuntansi (PPAK). Semarang: Universitas Diponegoro.

Naim, N. (2012). Character Building. Yogyakarta: Ar Ruzz Media.

Slameto. (2013). Belajar dan Faktor-faktor yang Mempengaruhinya. Jakarta: PT.Rineka Cipta.

Thoha, M. (2015). Kepemimpinan Dalam Manajemen (Cetakan ke). Jakarta: PT.Rajagrafindo Persada. 